\title{
Yield and apparent dry matter and nitrogen balances for muskmelon in a long-term comparison between an organic and a conventional low input cropping system
}

\author{
Michela Farneselli, Paolo Benincasa, Umberto Bonciarelli, Giacomo Tosti, Francesco Tei, \\ Marcello Guiducci \\ Dipartimento di Scienze Agrarie, Alimentari e Ambientali, Università degli Studi di \\ Perugia, Italy
}

\begin{abstract}
Nine-year yields and apparent balances of dry matter and nitrogen (N) are reported for muskmelon cultivated in a long-term comparison trial between an organic and a conventional low input system in Central Italy. In every year, yield, above ground biomass and $\mathrm{N}$ accumulation of each cash crop, green manure and weeds, and the partitioning between marketable yield and crop residues were determined. Apparent dry matter and nitrogen balances were calculated at the end of each crop cycle by taking into account the amounts of dry matter and ex novo $\mathrm{N}$ supplied to the system as green manure legume $\mathrm{Ndfa}$ (i.e., an estimate of $\mathrm{N}$ derived from the atmosphere via symbiotic fixation)
\end{abstract}

Correspondence: Paolo Benincasa, Dipartimento di Scienze Agrarie, Alimentari e Ambientali, Università degli Studi di Perugia, Borgo XX Giugno 74,06121 Perugia, Italy.

Tel.: +39.075.585.6325 - Fax: +39.075 .585 .6344 .

E-mail: paolo.benincasa@unipg.it

Key words: Green manure; crop residues; rotation; fertilisation; harvest; fruit quality.

Funding: this long-term research was partially supported by: i) SIMBIO-VEG Project (FISR 2005-2008, funded by Ministero dell'Ambiente, Italy); ii) BIOSYST II project (2007-2009, funded by Ministero Politiche Agricole, Alimentari e Forestali, Italy); and iii) IC-FAR project (PRIN 2010-2011, funded by Ministero Università e Ricerca, Italy).

Acknowledgements: the authors gratefully acknowledge the technicians of the Experimental Station of Agronomy and Field Crops of Papiano (Marsciano, Italy) for their precious support in running the experiments.

Conference presentation: SIA XLIII Congress, Pisa, 2014.

Received for publication: 15 December 2014.

Revision received: 25 May 2015.

Accepted for publication: 13 June 2015.

(C) Copyright M. Farneselli et al., 2015

Licensee PAGEPress, Italy

Italian Journal of Agronomy 2015; 10:630

doi:10.4081/ija.2015.630

This article is distributed under the terms of the Creative Commons Attribution Noncommercial License (by-nc 3.0) which permits any noncommercial use, distribution, and reproduction in any medium, provided the original author(s) and source are credited. and fertilisers, and those removed with marketable yield. Differences between systems varied across years. On average, organic muskmelon yielded $16 \%$ less than the conventional one, while the fruit quality was similar in the two cropping systems. Fruit ripening began one week later and it was more scaled than in the crop grown conventionally. This was the consequence of a slow initial growth of the organic crop, due to inadequate green manure $\mathrm{N}$ total supply or timing of $\mathrm{N}$ release. Moreover such a wide spaced crop ( 0.5 plants $\mathrm{m}^{-2}$, in rows $2 \mathrm{~m}$ apart) was not efficient in intercepting $\mathrm{N}$ released from green manure biomass incorporated broadcast. Compared to the conventional crop management, the organic crop management resulted in much higher organic matter supply to the soil and in higher residual $\mathrm{N}$ after harvest. Thus, the choice of cultivating wheat just after melon to prevent postharvest residual $\mathrm{N}$ loss appears a key strategy especially in organic systems. Fall-winter green manure crops contributed to the self-sufficiency of the organic system by supplying muskmelon with either $\mathrm{N}$ absorbed from the soil or ex novo legume Ndfa.

\section{Introduction}

The complex interactions among soil, plant, environment and cropping practices that occur in a cropping system become visible only very gradually because of the buffer capacity of soils and ecosystems (Kuo and Jellum, 2000; Constantin et al., 2010; Merbach et al., 2013). As an example, changes in soil nitrogen $(\mathrm{N})$ dynamics and organic matter contents can be accurately evaluated only in the long-term period, by long-term comparisons between cropping systems based on a same cash crop rotation (Fließbach et al., 2006; Thorup-Kristensen et al., 2012). Organic cropping systems have to face two main challenges, both affecting soil fertility and crop yield. The first challenge is to provide the crops with adequate amounts of available $\mathrm{N}$ at due time, and the second is to efficaciously manage weed and pest control (Askegaard et al., 2011). With respect to the management of soil fertility for spring-summer cash crops, several researches demonstrated that nitrogen can be efficaciously supplied by means of fertility building crops, thanks to either recycling of soil mineral $\mathrm{N}$ or legume $\mathrm{N}$ fixation (Thorup-Kristensen et al., 2003; de Ponti et al., 2012; ThorupKristensen et al., 2012; Tosti et al., 2012). Moreover, the use of green manures has been demonstrated to reduce the risk of nitrate leaching for some spring-summer crops such as maize and processing tomato (Salmeron et al., 2010; Gabriel et al., 2012; Tosti et al., 2014), provided a non-legume species is present as pure stand or intercropped with legumes. A long-term experiment for the comparison between an organic system and a conventional low input cropping system was carried out in Central Italy (Boldrini et al., 2007, 2008; Graziani et al., 
2012). Authors focused on the dynamics of dry matter (DM), nutrients and weeds for each system as a whole, while detailed data on single crops have been reported only for maize and processing tomato (Farneselli et al., 2013). In that long-term experiment, muskmelon (Cucumis melo L. var. reticulatus Naud.) is also present as a springsummer cash crop since 2005, being this species a major vegetable locally and worldwide, with 27.3 million tons (FAO, 2013).

Few studies on muskmelon dealt with the effect of organic and conventional cropping systems on yield and fruit quality either under protected (Curuk et al., 2004) and open-field conditions (Song et al., 2010). These authors found that yield and quality of organically grown melons were similar or even higher than those of conventionally grown ones. Other experiments did not study with muskmelon in organic systems but only focused on specific practices suitable for organic cultivation. Fernandes et al. (2003) found that using organic fertiliser and high fertigation frequency in greenhouse melon increased yield and total soluble content of fruits compared to those obtained with mineral fertilisers and low fertigation frequency. Ibarra et al. (2001) observed higher crop growth and yield cultivating muskmelon with soil mulch plus row cover, and Stagnari and Pisante (2010) found an increased total soluble solid content in muskmelon mulched with faba bean residues. To our knowledge, no study dealt with either yield or biomass and $\mathrm{N}$ balances for melon cultivated over many years in long-term comparisons between organic and conventional cropping systems. The present study is aimed at addressing these issues for melon as part of a rotation including vegetable and arable crops, in the mild Mediterranean environment of Central Italy.

\section{Materials and methods}

The field experiment was located at the Experimental Station of Agronomy and Field Crops of the Department of Agricultural, Food and Environmental Sciences - University of Perugia, located in Papiano (Central Italy, $43^{\circ} \mathrm{N}, 12.3^{\circ} \mathrm{E}, 165 \mathrm{~m}$ a.s.l.). Muskmelon (C. melo var. reticulatus, cv Bingo) was cultivated between 2005 and 2013 in an organic system (ORG) and in a conventional low input system (CONV). The two cropping systems were established in 1999 on two contiguous fields with homogeneous soil: Fluventic Haplustepts; 25\% sand, 38\% silt, $37 \%$ clay; $8.7 \mathrm{~g} \mathrm{~kg}^{-1}$ organic carbon (C), $9.9 \mathrm{C} / \mathrm{N}$ ratio, $19.7 \mu \mathrm{g} / \mathrm{kg}$ available phosphorus (Olsen), $214 \mu \mathrm{g} / \mathrm{kg}$ exchangeable potassium (international method), $\mathrm{pH}$ 8.05. In 1996, as required by the EU 2092/91 regulation, the ORG field underwent the transition from conventional to organic. From 1999 onwards, same rotations were set-up in the two fields and good ordinary management practices were always selected, in strict adherence to EU regulations for organic and conventional low input farming systems (European Commission, 1991, 1992). The basic sequence of cash crops over a 6-year period was: summer cereal (maize) - summer vegetable (processing tomato) - winter cereal (durum wheat) - grain legume (in most cases faba bean or common pea) - summer vegetable (sweet pepper, replaced by muskmelon starting from 2005) - winter cereal (soft wheat). In order to reproduce the steady-state running of the basic 6 -year rotation in a farm and test all the six crops of the sequence in each year, six different orderings were realised for both ORG and LOW field, each ordering starting with a different crop of the sequence. The six orderings were laid down on a completely randomised design with three replicates and plot sizes of $120 \mathrm{~m}^{2}$. The main differences between the two systems concerned $\mathrm{N}$ fertilisation management and crop protection.

Focusing on muskmelon cultivation, the $\mathrm{N}$ fertilisation in ORG was provided by green manure crops sown in autumn (hairy vetch+barley intercrop until 2010, pea+barley intercrop afterwards) integrated, in case, by an organic fertiliser (leather by-product) applied by fertigation. In CONV, the crop was fertigated by using a liquid fertiliser containing $7.5 \% \mathrm{NO}_{3}-\mathrm{N}, 7.5 \% \mathrm{NH}_{4}-\mathrm{N}$ and $15 \%$ urea- $\mathrm{N}$. The $\mathrm{N}$ rate was decided year by year depending on supposed $\mathrm{N}$ availability, based on fallspring weather. Muskmelon plants were transplanted by hands on the third decade of May at a density of 0.5 plants $\mathrm{m}^{-2}$, in single rows $2 \mathrm{~m}$ apart. In both systems weeds were controlled mechanically and manually in ORG, chemically in CONV. Pests (mainly aphids) and diseases (mainly powdery mildew) were controlled by allowed products in ORG and by chemicals in CONV. The crop was drip irrigated with a twice-aweek schedule to fully satisfy crop water requirements estimated by the Penman-Monteith equation and specific crop coefficients (Allen et al., 1998). Depending on the year, the total amount of irrigation water ranged from 250 to $350 \mathrm{~mm}$. Fruits were harvested at half to full slip stage every 2-3 days starting from the end of July until the first decade of September, depending on the year. At each harvest date, non-marketable fruits (i.e., cracked, damaged, rotten, misshapen, and below and above marketable size) and marketable fruits were separated, counted and weighted. The cumulative yield was calculated as the sum of marketable yields obtained in all harvest dates. The mean weight of marketable fruits was calculated as the ratio of the cumulative marketable yield to the number of marketable fruits picked up in all harvests. Total soluble solid content (as ${ }^{\circ} \mathrm{Brix}$ ) was measured by a digital refractometer (PR-101; Atago Co. Ltd., Tokyo, Japan) on 5 marketable fruits per plot. In every year, above ground biomass and $\mathrm{N}$ accumulated in green manures, marketable fruits and crop residues (including nonmarketable fruits and weeds) were determined by plant samplings and lab-analysis of organic $\mathrm{N}$ concentration in DM (Kjeldhal method). Green manure plants were sampled at the incorporation time (from the end of March to mid-April, depending on the year) from a surface area of $1 \mathrm{~m}^{2}$ per plot. The above ground biomass of companion legume and non-legume species in the intercrop was separated by hand, weighed, oven dried and ground to a fine powder to analyse $\mathrm{N}$ concentration. Muskmelon plants and weeds were harvested at the end of each cash crop cycle (i.e., at the last harvest date), from a sampling area of $4 \mathrm{~m}^{2}$ to determine fresh weights and dry matter and $\mathrm{N}$ concentration on subsamples.

Apparent dry matter and $\mathrm{N}$ balances were calculated at the end of each crop cycle according to the following equations:

$$
\Delta \mathrm{DM}=\mathrm{DM}_{\mathrm{GM}}+\mathrm{DM}_{\mathrm{OF}}+\mathrm{DM}_{\mathrm{CC}}-\mathrm{DM}_{\mathrm{MY}}
$$

where:

$\Delta \mathrm{DM}=$ apparent variation of dry matter in the system;

$\mathrm{DM}_{\mathrm{GM}}=$ above ground dry matter from green manures (including weeds);

$\mathrm{DM}_{\mathrm{OF}}=$ dry matter from organic fertilisers;

$\mathrm{DM}_{\mathrm{CC}}=$ above ground dry matter from the cash crop (including weeds); $\mathrm{DM}_{\mathrm{MY}}=$ dry matter removed from the field with marketable yield;

$$
\Delta \mathrm{N}=\mathrm{Ndfa}_{\mathrm{GM}}+\mathrm{N}_{\mathrm{F}}-\mathrm{N}_{\mathrm{MY}}
$$

where:

$\Delta \mathrm{N}=$ apparent variation of $\mathrm{N}$ in the system (i.e., residual $\mathrm{N}$ in the soil); $\mathrm{Ndfa}_{\mathrm{GM}}=$ above ground $\mathrm{N}$ derived from atmosphere accumulated by green manure legumes;

$\mathrm{N}_{\mathrm{F}}=$ fertiliser- $\mathrm{N}$;

$\mathrm{N}_{\mathrm{MY}}=\mathrm{N}$ removed from the field with marketable yield.

Therefore, the actual ex novo $\mathrm{N}$ supplied to the system was calculated by taking into account, besides fertiliser-N, only the amount of above ground green manure $\mathrm{N}$ derived from the atmosphere (Ndfa). This was estimated to account for $80 \%$ of total above ground legume $\mathrm{N}$ of the hairy vetch and pea mixed with barley, according to Boldrini et al. 
(2007). The remaining $20 \%$ was thus assumed to be adsorbed from the soil and not considered in the balance because already present in the system. The dry biomass and $\mathrm{N}$ accumulated in roots was not taken into account for apparent balances. The ANOVA of data was performed by considering Year and Cropping system as fixed effects. Least significant differences were used to compare the means for the Year $x$ Cropping system combinations. Statistical analysis was performed by using the software R (R Development Core Team, 2013).

\section{Results}

The marketable yield of melon varied across years (Table 1) but most of the times it was lower in ORG than in CONV, except for 2006 and

Table 1. Marketable yield $\left(\mathrm{Mg} \mathrm{ha}^{-1}\right)$ and number of fruits per hectare $\left(\mathrm{ha}^{-1} \times 1000\right)$ in muskmelon grown in an organic and in a conventional low input cropping system across years 2005-2013. The effect of the Year was not significant in the ANOVA, the effect of Cropping system and the interaction Year $x$ Cropping system were significant $(\mathrm{P}<0.01)$.

\begin{tabular}{|c|c|c|c|c|}
\hline \multirow[t]{2}{*}{ Year } & \multicolumn{2}{|c|}{$\begin{array}{l}\text { Marketable yield } \\
\left(\mathrm{Mg} \mathrm{ha}^{-1}\right)\end{array}$} & \multicolumn{2}{|c|}{$\begin{array}{l}\text { Fruits ha }{ }^{-1} \\
(\times 1000)\end{array}$} \\
\hline & ORG & CONV & ORG & CONV \\
\hline 2005 & 18.1 & 22.5 & 14.9 & 19.1 \\
\hline 2006 & 47.1 & 38.1 & 28.1 & 21.2 \\
\hline 2007 & 44.8 & 41.9 & 28.1 & 29.2 \\
\hline 2008 & 37.9 & 43.6 & 21.9 & 24.1 \\
\hline 2009 & 54.0 & 59.7 & 35.3 & 40.1 \\
\hline 2010 & 32.1 & 49.8 & 23.2 & 38.4 \\
\hline 2011 & 35.6 & 67.6 & 22.4 & 41.5 \\
\hline 2012 & 50.2 & 54.5 & 26.1 & 30.2 \\
\hline 2013 & 29.8 & 40.6 & 24.5 & 30.3 \\
\hline $\operatorname{LSD}(\mathrm{P}=0.05)$ & \multicolumn{2}{|c|}{5.3} & \multicolumn{2}{|c|}{4.4} \\
\hline
\end{tabular}

ORG, organic cropping system; CONV, conventional low input cropping system; LSD, least significant difference test.

Table 2. Mean marketable fruit weight (MFr-W, kg) and total soluble solid content $\left({ }^{\circ} \mathrm{Brix}\right)$ in muskmelon grown in an organic and in a conventional low input cropping system across years 20052013. The effects of the Year and Cropping system were not significant in the ANOVA, the interaction Year $x$ Cropping system was significant $(P<0.01)$.

\begin{tabular}{lcccc} 
Year & \multicolumn{2}{c}{ MFF-W (kg) } & \multicolumn{2}{c}{${ }^{\circ}$ Brix } \\
& ORG & CONV & ORG & CONV \\
2005 & 1.21 & 1.18 & 14.0 & 13.7 \\
2006 & 1.67 & 1.79 & 14.0 & 13.3 \\
\hline 2007 & 1.59 & 1.43 & 15.0 & 14.1 \\
2008 & 1.74 & 1.81 & 13.4 & 13.4 \\
\hline 2009 & 1.53 & 1.49 & 13.2 & 12.5 \\
2010 & 1.39 & 1.29 & 13.0 & 13.5 \\
\hline 2011 & 1.59 & 1.63 & 12.7 & 14.8 \\
2012 & 1.93 & 1.81 & 12.9 & 12.2 \\
\hline 2013 & 1.22 & 1.34 & 12.0 & 13.0 \\
LSD (P=0.05) & & 0.11 & & \multicolumn{2}{c}{0.9} \\
\hline
\end{tabular}

ORG, organic cropping system; CONV, conventional low input cropping system; LSD, least significant difference test.
2007, when the opposite was observed. The 9-year average yield was $16 \%$ lower in ORG than in CONV. A similar trend was observed for the number of marketable fruits per hectare (Table 1), with a 9-year average 18\% lower in ORG than in CONV. The mean weight of one marketable fruit and the total soluble solid content were not substantially affected by the cropping system (Table 2): although some differences might result significant, the effect of the cropping system was generally little and not univocal across years. Compared to CONV, ORG resulted in an average one week delay of the beginning of melon harvest and in a more scaled harvest period, with 14 harvest passages in ORG $v s 12$ in CONV, on a 9 -year average (Figure 1). The $50 \%$ of the total yield was harvested in the first three passages for CONV, while two more passages were needed for ORG (Figure 1). Figure 2 shows the amount of DM supplied to the system, calculated as the sum of dry matter from green manures, organic fertilisers, weeds, and the melon crop

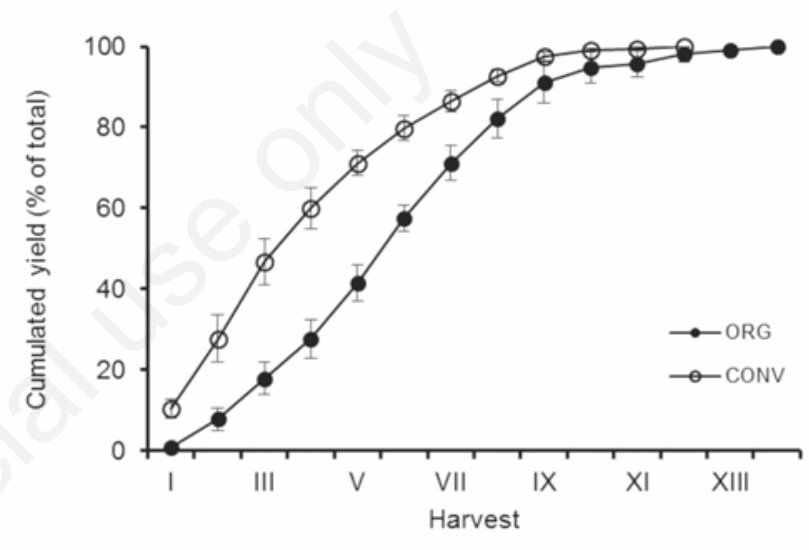

Figure 1. Cumulated marketable yield by harvest passages in muskmelon grown in an organic (ORG=full circles) and in a conventional low input ( $\mathrm{CONV}=$ empty circles) cropping system across years 2005-2013. Vertical bars represent \pm 1 standard error of the mean.

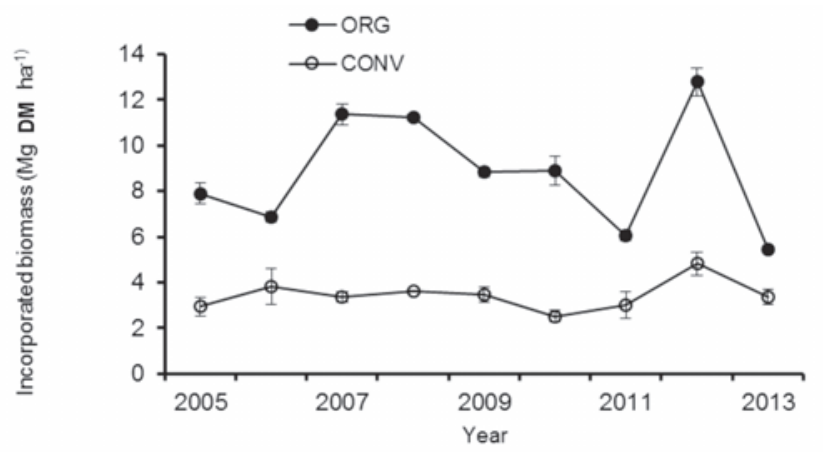

Figure 2. Amount of biomass $\left[\mathrm{Mg} \mathrm{ha}^{-1}\right.$ of dry matter (DM)] incorporated into the soil (i.e., sum of DM of above ground crop residuals, weeds, green manure and organic fertilisers) in muskmelon grown in an organic (ORG=full circles) and in a conventional low input $(\mathrm{CONV}=$ empty circles) cropping system across years 2005-2013. Vertical bars represent \pm 1 standard error of the mean. 
residues. This amount was much higher in ORG than in CONV (8.8 vs 3.4 $\mathrm{Mg} \mathrm{DM} \mathrm{ha}^{-1}$, respectively, as a 9-year average). The DM supply was also more variable in ORG than in CONV, but differences from CONV were always positive and significant, ranging from $+62 \%$ to $+165 \%$.

The actual $\mathrm{N}$ supply to the system related to melon cultivation (i.e., green manure legume Ndfa and fertiliser-N) varied year by year in both systems (Figure 3). Compared to the $\mathrm{N}$ rate used for the melon crop in CONV, the supply obtained for the melon crop in ORG was lower in five years out of nine, higher in three years and equal in one, with a 9-year average of $89 \mathrm{~kg} \mathrm{ha}^{-1}$ in ORG and $95 \mathrm{~kg} \mathrm{ha}^{-1}$ in CONV.

The melon $\mathrm{N}$ use efficiency (NUE), calculated here as the marketable yield dry matter per unit of $\mathrm{N}$ supplied to the crop, varied year by year, with wider variations in ORG (Figure 4 ). The effect of cropping systems was not univocal, however in $2 / 3$ of the years the melon NUE was lower in ORG than in CONV. The residual $\mathrm{N}$ in the soil after harvest (i.e., the actual $\mathrm{N}$ supply minus the $\mathrm{N}$ removed from the soil with marketable yield) varied year by year in both systems (Figure 5). On average over all years, the residual $\mathrm{N}$ was much higher in ORG than in CONV (19.8 $\mathrm{kg} \mathrm{ha}^{-1} v s-8.4 \mathrm{~kg} \mathrm{ha}^{-1}$, respectively). In particular, the value of residual $\mathrm{N}$ in $\mathrm{ORG}$ was positive in six out of nine years and in four of them it was close to, or higher than, $60 \mathrm{~kg} \mathrm{~N} \mathrm{ha}^{-1}$. On the contrary, the value of residual $\mathrm{N}$ in CONV was often negative or, when positive, it was very low $\left(<20 \mathrm{~kg} \mathrm{ha}^{-1}\right)$.

\section{Discussion}

The inter-annual variability of melon marketable yield was mainly a consequence of weather conditions before and during each crop cycle. The very low yield recorded in 2005 in both cropping systems was caused by water stagnation in the soil that compromised crop establishment and initial growth. A similar effect was observed by Farneselli et al. (2013) also for processing tomato grown in the same year and experiment. Similar soil conditions occurred also in 2011 and 2012 in CONV and for this reason a supplementary $\mathrm{N}$ fertilisation rate was provided aimed at mitigating negative effects on crop growth and yield. Such an adjustment of the N supply was not always possible in ORG. Indeed, the generally lower and more variable marketable yield achieved in ORG across years (Table 1) was mainly a consequence of the lower and unpredictable amount of $\mathrm{N}$ available to crops from green manures and organic fertilisers (see later on). Song et al. (2010) found similar yields for muskmelon grown in organic and conventional systems, but they considered only one year and supplied the same $\mathrm{N}$ amount from fertilisers in both systems. The moderate reduction of melon marketable yield observed in ORG compared to CONV is in line with the overall $20 \%$ reduction reported by Thorup-Kristensen et al. (2012) for organically grown vegetables compared to conventionally grown ones in a mixed rotation with cereals. Nonetheless, the yields we recorded in ORG were similar to those reported by Song et al. (2010) and higher than those obtained by Benincasa et al. (2014) for muskmelon grown conventionally in a similar environment.

The lower yields recorded in ORG with respect to CONV resulted from less fruits per hectare (Table 1), while the average fruit weights were similar in the two cropping systems (Table 2). Sharma et al. (2014) found a positive correlation between fruit yield and fruit weight but this stood for crops grown with different irrigation volumes, while in our experiment the same amount of water was distributed in ORG and CONV. As known, fruit weight in muskmelon is mainly affected by water availability (Cabello et al., 2009).

The total soluble solid content of melon observed in ORG and CONV is in the range reported in the literature (Cabello et al., 2009; Stagnari and Pisante, 2010; Song et al., 2010; Benincasa et al., 2014). As pro-

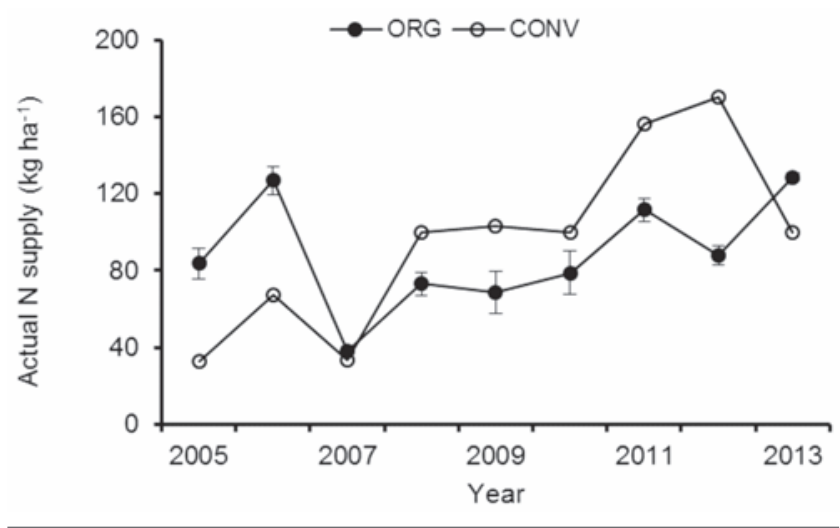

Figure 3. Amount of ex-novo $\mathrm{N}\left(\mathrm{kg} \mathrm{ha}^{-1}\right)$ supplied to the soil (i.e., green manure legume Ndfa plus fertiliser $N$ ) in muskmelon grown in an organic (ORG=full circles) and in a conventional low input $(C O N V=$ empty circles) cropping system across years 2005 2013. Vertical bars represent \pm 1 standard error of the mean.

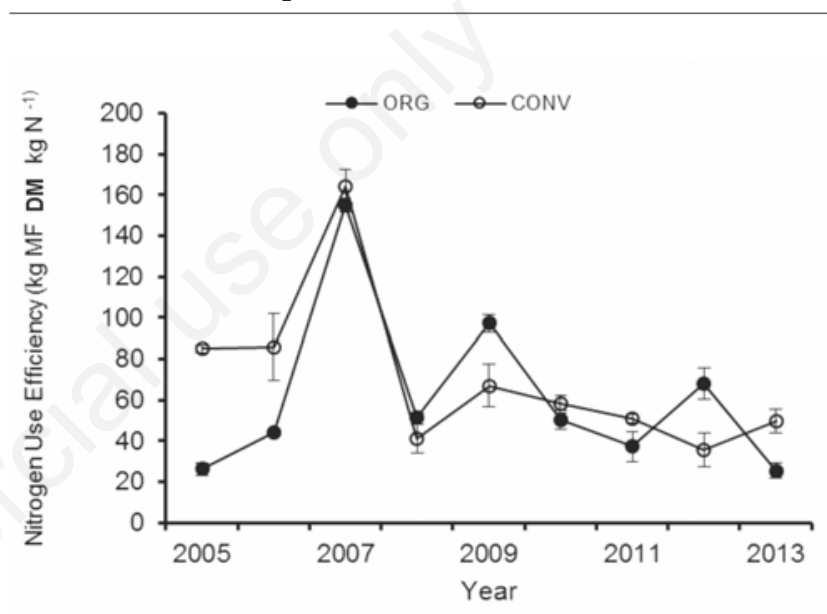

Figure 4. Nitrogen use efficiency (kg dry matter of marketable fruit produced per $\mathrm{kg}$ of $\mathrm{N}$ supplied) in muskmelon grown in an organic (ORG=full circles) and in a conventional low input (CONV=empty circles) cropping system across years 2005-2013. Vertical bars represent \pm 1 standard error of the mean.

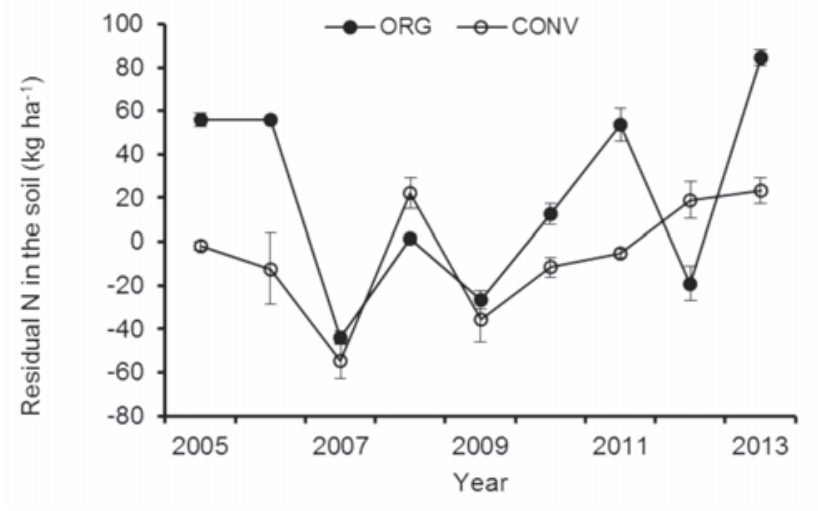

Figure 5. Residual nitrogen in the soil at the end of the crop cycle (i.e., green manure legume $\mathrm{Ndfa}$ plus fertiliser $\mathrm{N}$ minus $\mathrm{N}$ removed with marketable yield) in muskmelon grown in an organic (ORG=full circles) and in a conventional low input (CONV=empty circles) cropping system across years 2005-2013. Vertical bars represent \pm 1 standard error of the mean. 
posed by Lingle and Dunlap (1987), a great part of sugars accumulated in muskmelon fruits is translocated from other plant organs, the biomass of which was similar in the two systems (i.e., crop residues at final harvest in ORG and CONV were 3.3 and $3.4 \mathrm{Mg} \mathrm{ha}^{-1}$, respectively, on average over all years).

The average one week delay of fruit ripening and the more scaled harvest observed in ORG compared to CONV can be explained with the slower initial growth related to the lower amount of $\mathrm{N}$ available to the crop, due to lower (and variable) amount and/or release rate of $\mathrm{N}$ from green manure biomass and organic fertilisers, while the $\mathrm{N}$ provided in CONV could be decided with more accuracy and it was all ready to use. The more scaled harvest in organic crops could be not necessarily a drawback for those organic farms, which use to sell their products directly on farm.

The higher amount of DM incorporated into the soil associated with melon cultivation in ORG compared to CONV confirms findings by Farneselli et al. (2013) on processing tomato and maize and is mainly due to green manure biomass incorporation, while the amount of biomass from organic fertilisers was risible and that from crop residues was similar in the two systems.

As already mentioned, the inter-annual variation of $\mathrm{N}$ supply in CONV was decided according to fall-winter weather and adjusted according to soil and weather conditions during the initial growth of melon. In ORG, the inter-annual variability of $\mathrm{N}$ supply was due to variable green manure $\mathrm{N}$ accumulation and it could not be always adjusted as needed. For example, in 2005, 2006 and 2013, the $\mathrm{N}$ supply from green manures was higher than that decided for CONV and of course no adjustment was possible. On the other hand, in most of the years the $\mathrm{N}$ supply from green manures was lower than in CONV (Figure 3) and the integration with organic fertiliser was sometime inadequate to approximate the $\mathrm{N}$ rate in CONV. It is well known that a delay in early crop growth generally causes lower total biomass accumulation and yield at final harvest both in short- and long-cycle vegetables (Tei et al., 2002, 2003). The variability and unpredictability of green manure $\mathrm{N}$ depended also from biomass proportion between legumes and non-legumes in the intercrop, which varied year by year with soil and season weather (Tosti et al., 2010). Moreover, depending on temperature in early spring, the $\mathrm{N}$ available to the crop (i.e., that released by mineralisation) from green manure biomass and organic fertilisers was not predictable. It should be considered that in rainy fall-winter season, the $\mathrm{N}$ absorbed from the soil by green manures represents $\mathrm{N}$ prevented from leaching, but in dry fall-winter seasons, that $\mathrm{N}$ would remain in the soil anyway, thus its uptake by green manures causes pre-emptive competition towards the following cash crop (ThorupKristensen et al., 2003). In 2007, the melon crop was supplied with a very low amount of $\mathrm{N}$ in both systems in the assumption that the mild and dry fall-spring season could have left a relevant amount of available $\mathrm{N}$ in the soil. This was then confirmed by the good yields recorded in that year in both systems (Table 1). The much higher $\mathrm{N}$ supply provided to the crop in CONV compared to ORG in 2011 and 2012 was decided to allow the crop recover from the slow initial crop growth due to soil water stagnation. Such water stagnation was not observed in ORG, maybe thanks to water consumption by the green manure crop and to the positive effect of biomass incorporation on soil structure and water infiltration.

The values of green manure $\mathrm{N}$ supply observed in our experiment were generally lower than those reported by Benincasa et al. (2010) and Tosti et al. (2012) for the same location. This because these authors grew green manures within conventional systems where base soil fertility was higher and some benefits lasted from weed control on previous cash crops.

Our estimate of the ex-novo $\mathrm{N}$ input in ORG (Figure 3) does not take into account root Ndfa (see Materials and methods section) that is known to account for around 5-10\% of total plant Ndfa (Mazzoncini et al., 2010). Moreover in rainy fall-winter seasons, green manures likely prevented soil mineral N loss (Tonitto et al., 2006; Salmeron et al., 2010; Tosti et al., 2010; Askegaard et al., 2011; Thorup-Kristensen et al., 2012; Tosti et al., 2014) so contributing to increase N husbandry in $\mathrm{ORG}$.

The frequently lower NUE recorded for melon in ORG compared to CONV (Figure 4) was unexpected being $\mathrm{N}$ supply generally higher in CONV, because the NUE is known to decrease with increasing $\mathrm{N}$ availability (Tei et al., 1999). Moreover, this result is opposite to that obtained for processing tomato in the same experiment (Farneselli $e t$ al., 2013). This can be explained taking into account the different characteristics of the two crops. Compared to processing tomato, melon is known to have more difficult plant establishments and slower root growth (Lingle and Dunlap, 1987). In addition, plant spacing was much wider in melon ( 0.5 plants $\mathrm{m}^{-2}$ with rows $2 \mathrm{~m}$ apart) than in processing tomato ( 3.2 plants $\mathrm{m}^{-2}$ with rows $1 \mathrm{~m}$ apart; Farneselli, personal communication, 2013) so that the former was likely less efficient in intercepting $\mathrm{N}$ released from green manure biomass incorporated broadcast, especially in early stages. Båth (2000) used the term asynlocation for such a spatial lack of matching between green manure $\mathrm{N}$ placement and cash crop rooting zone. On the other hand, the $\mathrm{N}$ rate in CONV was localised and split by means of drip fertigation, which is known to allow very high NUE values.

Anyway, the NUE of melon in ORG was in the range recorded by Cabello et al. (2009), except for the very high NUE recorded in 2007 for both systems, due to the very low amount of $\mathrm{N}$ supplied that year. On the other hand, the very high $\mathrm{N}$ rate used in CONV compared to ORG in 2012 reduced melon NUE in the former system.

The higher residual N (Figure 5) recorded in ORG compared to CONV is the expected consequence of the lower melon NUE in ORG discussed above. Most of this $\mathrm{N}$ can be considered mineral or easy to mineralise in a short-time interval, thus, in view of a rainy fallwinter climate it would be likely lost in case of bare soil (Askegaard et al., 2011). However, our rotation included a winter cereal as a following crop, which could both take advantage of the residual $\mathrm{N}$ fertility and limit the risk of leaching. As already demonstrated by Thorup-Kristensen et al. (2012), growing cereals as part of crop rotation including vegetables may improve $\mathrm{N}$ husbandry, since they are more efficient than vegetables in depleting soil $\mathrm{N}$ and recover it also from deep soil layers. The organic portion of the high residual $\mathrm{N}$ recorded in ORG should contribute to increase the base soil $\mathrm{N}$ fertility and improve soil quality parameters (Grignani et al., 2007; Constantin et al., 2010) compared to CONV, but these aspects need to be discussed elsewhere on the basis of soil samplings taken at long-term intervals in all the field sectors of the rotation (see Materials and methods section).

\section{Conclusions}

Our results on muskmelon cultivated for nine years in a long-term comparison trial between an organic and a conventional low input system indicate that yield of organic muskmelon was slightly lower than that of the conventional one, while fruit size and total soluble solid content was not affected by the cropping system. Fruit ripening (and harvest) in organic melon began one week later and was more scaled. The main limitation for organic melon was represented by the slow initial crop growth. The possible causes for this evidence were: limiting green manure nitrogen supply in some years, generally when winter was cold; inadequate timing of $\mathrm{N}$ release from green manures and organic fertilisers in some years, generally when spring was cold; 
inadequate placement of green manure nitrogen, because green manure biomass was incorporated broadcast and such a wide spaced crop ( 0.5 plants $\mathrm{m}^{-2}$ in rows $2 \mathrm{~m}$ apart) with slow initial root growth was not efficient in intercepting nitrogen. In fact, organic melon resulted in lower nitrogen use efficiency and higher residual nitrogen in the soil compared to conventional melon. The choice of cultivating wheat as following crop should have limited the residual nitrogen loss and contributed to improve the nitrogen husbandry for both systems, especially for the organic one.

\section{References}

Allen RG, Pereira LS, Raes D, Smith M, 1998. Crop evapotranspiration. Guidelines for computing crop water requirements. FAO irrigation and drainage; paper no. 56. Food and Agriculture Organisation (FA0), Rome, Italy.

Askegaard M, Olesen JE, Rasmussen IA, Kristensen K, 2011. Nitrate leaching from organic arable crop rotation is mostly determined by autumn field management. Agric. Ecosyst. Environ. 142:149-60.

Båth B, 2000. Matching the availability of $n$ mineralised from greenmanure crops with the N-demand of field vegetables. Agraria Doctoral Dissertation (Ph.D.), Swedish University of Agricultural Sciences, Uppsala, Sweden, 222:29-1.

Benincasa P, Massoli A, Polegri L, Concezzi L, Onofri A, Tei F, 2014. Optimising the use of plastic protective covers in filed grown melon on a farm scale. Ital. J. Agron. 9:8-14.

Benincasa P, Tosti G, Tei F, Guiducci M, 2010. Actual N availability from winter catch crops used for green manuring in maize cultivation. J. Sust. Agric. 34:705-23.

Boldrini A, Benincasa P, Gigliotti G, Businelli D, Guiducci M, 2008. Effects of an organic and a conventional cropping system on soil fertility. pp 324-327 in Proc. 2nd ISOFAR Conference, 18-20 June, Modena, Italy. Organic e-prints ID number 12381.

Boldrini A, Benincasa P, Tosti G, Tei F, Guiducci M, 2007. Apparent N balance in organic and conventional low input cropping system. pp 264-267 in Proc. 3rd International QLIF Congress, 20-23 March, Hohenheim, Germany. Organic e-prints ID number 9885.

Cabello MJ, Castellanos MT, Romojaro F, Martinez-Madrid C, Ribas F, 2009. Yield and quality of melon grown under different irrigation and nitrogen rates. Agric. Water Manag. 96:866-74.

Constantin J, Mary B, Laurent F, Aubrion G, Fontane A, Kerveillant P, Beaudoin N, 2010. Effects of cath crops, no till and reduced nitrogen fertilization on nitrogen leaching and balance in three longterm experiments. Agric. Ecosys. Environ. 135:268-78.

Curuk S, Sermenli T, Mavi K, Evrendilek F, 2004. Yield and fruit quality of watermelon (Citrullus lanautus (Thumb) Matsum. \& Nakai.) and melon (Cucumis melo L.) under protected organic and conventional farming systems in a Mediterranean region of Turkey. Biol Agric. Hortic. 22:173-83.

de Ponti T, Rijk B, van Ittersum MK, 2012. The crop yield gap between organic and conventional agriculture. Agric. Syst. 108:1-9.

European Commission, 1991. Council regulation (EEC) No 2092/91 of 24 June 1991 on organic production of agricultural products and indications referring thereto on agricultural products and foodstuffs. In: Official Journal, L 198, 22/7/1991, pp 1-95.

European Commission, 1992. Council Regulation (EEC) No 2078/92 of 30 June 1992 on agricultural production methods compatible with the requirements of the protection of the environment and the maintenance of the countryside. In: Official Journal, L 215, 30/7/1992, pp 85-90.

FAO (Food and Agriculture Organisation), 2013. FAOSTAT. Available from: http:/faostat3.fao.org/home/index.html Accessed: 24/10/2014.

Farneselli M, Benincasa P, Tosti G, Pace R, Tei F, Guiducci M, 2013. Nineyear results on maize and processing tomato in an organic and in a conventional low input cropping system. Ital. J. Agr. 8:9-13.

Fernandes ALT, Rodrigues GP, Testezlaf R, 2003. Mineral and organomineral fertigation in relation to quality of greenhouse cultivated melon. Sci. Agric. 60:149-54.

Fließbach A, Oberholzer HR, Gunst L, Mäder P, 2006. Soil organic matter and biological soil quality indicators after 21 years of organic and conventional farming. Agric. Ecosys. Environ. 118:273-84.

Gabriel JL, Munoz-Carpena R, Quemada M, 2012. The role of cover crops in irrigated systems: Water balance, nitrate leaching and soil mineral nitrogen accumulation. Agric. Ecosyst. Environ. 155:50-61.

Graziani F, Onofri A, Pannacci E, Tei F, Guiducci M, 2012. Size and composition of weed seedbank in long-term organic and conventional low-input cropping systems. Eur. J. Agron. 39:52-61.

Grignani C, Zavattaro L, Sacco D, Monaco S, 2007. Production, nitrogen and carbon balance of maize-based forage systems. Eur. J. Agron. 26:442-53.

Ibarra L, Flores J, Diaz-Perez JC, 2001. Growth and yield of muskmelon in response to plastic mulch and row covers. Sci. Hort. 87: 139-145.

Kuo S, Jellum EJ, 2000. Lon-term winter cover cropping effects on corn (Zea mais L.) production and soil nitrogen availability. Bio. Fertil. Soils 31:470-7.

Lingle SE, Dunlap JR, 1987. Sucrose metabolism in netted muskmelon fruit development. Plant Physiol. 84:386-9.

Mazzoncini M, Canali S, Giovannetti M, Castagnoli M, Tittarelli F, Antichi D, Nannelli R, Cristani C, Barberi P, 2010. Comparison of organic and conventional stockless arable systems: a multidisciplinary approach to soil quality evaluation. Appl. Soil Ecol. 44:124-32.

Merbach W, Herbst F, Eißner H, Schmidt L, Deubel A, 2013. Influence of different long-term mineral-organic fertilization on yield, nutrient balance and soil on C and N contents of a sandy loess (Haplic Phaeozem) in middle Germany. Arch. Agron. Soil Sci. 59:1059-71.

R Development Core Team, 2013. R: A language and environment for statistical computing. Version 2.13.1. R Foundation for Statistical Computing, Vienna, Austria.

Salmeron M, Cavero J, Quilez D, Isla R, 2010. Winter cover crops affect monoculture maize yield and nitrogen leaching under irrigated mediterranean conditions. Agron. J. 102:1700-9.

Sharma SP, Leskovar DI, Crosby KM, Volder A, Ibrahim AMH, 2014. Root growth, yield, and fruit quality response of reticulatus and inodorus melons (Cucumis melo L.) to deficit subsurface drip irrigation. Agric. Water Manage. 136:75-85.

Song S, Lehne P, Le J, Ge T, Huang D, 2010. Yield, fruit quality and nitrogen uptake of organically and conventionally grown muskmelon with different inputs of nitrogen, phosphorus, and potassium. J. Plant Nutr. 33:130-41.

Stagnari F and Pisante M, 2010. Managing faba been residues to enhance the fruit quality of the melon (Cucumis melo L.) crop. Sci. Hort. 126:317-23.

Tei F, Benincasa P, Guiducci M, 1999. Nitrogen fertilisation of lettuce, processing tomato and sweet pepper: yield, nitrogen uptake and the risk of nitrate leaching. Acta Hort. 506:61-7.

Tei F, Benincasa P, Guiducci M, 2002. Effect of N availability on growth, $\mathrm{N}$ uptake, light interception and photosynthetic activity in processing tomato. Acta Hort. 571:209-13.

Tei F, Benincasa P, Guiducci M, 2003. Critical nitrogen concentration in lettuce. Acta Hort. 627:187-94.

Thorup-Kristensen K, Dresboll DB, Kristensen HL, 2012. Crop yield, root growth, and nutrient dynamics in a conventional and three organic cropping systems with different levels of external inputs 
and $\mathrm{N}$ re-cycling through fertility building crops. Eur. J. Agron. $37: 66-82$.

Thorup-Kristensen K, Magid J, Jensen LS, 2003. Catch crops and green manures as biological tools in nitrogen management in temperate zones. Adv. Agron. 79:227-302.

Tonitto C, David MB, Drinkwater LE, 2006. Replacing bare fallows with cover crops in fertilizer-intensive cropping systems: A meta-analysis of crop yield and N dynamics. Agric. Ecosyst. Environ. 112:58-72.

Tosti G, Benincasa P, Farneselli M, Pace R, Tei F, Guiducci M, Thorup-
Kristensen K, 2012. Green manuring effect of pure and mixed barley-hairy vetch winter cover crops on maize and processing tomato N nutrition. Eur. J. Agron. 43:136-46.

Tosti G, Benincasa P, Farneselli M, Tei F, Guiducci M, 2014. Barleyhairy vetch mixture as cover crop for green manuring and the mitigation of N leaching risk. Eur. J. Agron. 54:34-9.

Tosti G, Benincasa P, Guiducci M, 2010. Competition and facilitation in hairy vetch-barley intercrops. Ital. J. Agron 5:239-47. 